\title{
Comparison of the Rheological Properties of Plant Proteins from Various Sources for Extrusion Applications
}

\author{
Patrick Wittek $^{1}\left(\mathbb{D}\right.$, Goeran Walther ${ }^{2}$, Heike P. Karbstein ${ }^{1}(\mathbb{D})$ and M. Azad Emin ${ }^{1, *}$ \\ 1 Institute of Process Engineering in Life Sciences, Chair of Food Process Engineering, \\ Karlsruhe Institute of Technology, 76131 Karlsruhe, Germany; patrick.wittek@kit.edu (P.W.); \\ heike.karbstein@kit.edu (H.P.K.) \\ 2 General Mills, R\&D, James Ford Bell Technical Center, Golden Valley, MN 55427, USA; \\ goeran.walther@genmills.com \\ * Correspondence: azad.emin@kit.edu; Tel.: +49-(0)721-608-48311
}

Citation: Wittek, P.; Walther, G.;

Karbstein, H.P.; Emin, M.A.

Comparison of the Rheological

Properties of Plant Proteins from Various Sources for Extrusion

Applications. Foods 2021, 10, 1700.

https://doi.org/10.3390/foods10081700

Academic Editor:

Maria Antonietta Ciardiello

Received: 15 June 2021

Accepted: 16 July 2021

Published: 22 July 2021

Publisher's Note: MDPI stays neutral with regard to jurisdictional claims in published maps and institutional affiliations.

Copyright: (c) 2021 by the authors. Licensee MDPI, Basel, Switzerland. This article is an open access article distributed under the terms and conditions of the Creative Commons Attribution (CC BY) license (https:// creativecommons.org/licenses/by/ $4.0 /)$

\begin{abstract}
Plant proteins in foods are becoming increasingly popular with consumers. However, their application in extruded products remains a major challenge, as the various protein-rich raw materials (e.g., from different plant origins) exhibit very different material properties. In particular, the rheological properties of these raw materials have a distinct influence on the extrusion process and must be known in order to be able to control the process and adjust the product properties. In this study, process-relevant rheological properties of 11 plant-based protein-rich raw materials (differing in plant origin, protein content, and manufacturer) are determined and compared. The results demonstrate distinct differences in the rheological properties, even when plant origin and protein content are identical. Time sweeps reveal not only large differences in development of viscosity over time, but also in magnitude of viscosity (up to 15-fold difference). All materials exhibit gel behaviour and strain thinning behaviour in the strain sweeps, whereas their behaviour in the non-linear viscoelastic range differs greatly. Typical relaxation behaviour of viscoelastic materials could be observed in the stress relaxation tests for all materials. Comparison of the maximum achieved shear stress, which correlates with the elastic properties, reveals an up to 53-fold difference. The results of this study could serve as a starting point for adapting raw material selection and composition to process and product design requirements and help to meet the challenge of applying plant-based proteins in food extrusion.
\end{abstract}

Keywords: plant protein; extrusion; rheological properties; viscoelasticity; closed cavity rheometer

\section{Introduction}

Interest in the use of plant proteins in extruded foods is steadily increasing [1,2]. Protein-rich raw materials from plant origin can be used either as the main ingredient, as in some meat analogues [3-6], or to increase the protein content of traditional starch-based products, such as in breakfast cereals or snacks [7-9].

These protein-rich raw materials, i.e., flours, concentrates, and isolates, can be produced from various plants. The most commonly used raw materials in food extrusion are from soybean, wheat, and pea [10]. However, recent developments have also demonstrated the potential use of many other plant protein sources for extrusion applications, such as oat [11], canola [12], lupin [13], peanut [14-16], and hemp [17].

The proteins in these raw materials differ in their amino acid composition and molecular structure [18,19]. Both parameters are initially determined by the plant origin of the raw material, e.g., the plant species or the growth conditions of the plant. However, the molecular structure of the proteins can be strongly influenced by further processing steps necessary to produce the protein-rich raw materials, such as the removal of lipid and polysaccharide components [20]. Thus, a variety of resulting molecular structures and 
significant differences in the material properties of the raw materials arises [19,21], even if the plant origin and protein content are the same [5,22-24].

In particular, the rheological properties of these raw materials have a distinct influence on the extrusion process. For example, the shear stresses generated by screw rotation, which are responsible for physical and chemical changes, are a function of viscosity $[25,26]$. In processes where product structure is determined by expansion at the die exit (such as directly expanded cereals), structuring depends on elasticity in addition to viscosity [27-30]. And the flow behaviour in the cooling die, which is important for the product structure of high moisture extruded meat analogues, is also a function of the rheological properties [3,31-33].

In order to control the process and adjust the product properties, it is therefore necessary to know how the rheological properties are determined by the raw material selection. However, rheological measurements at process-relevant conditions, i.e., at high temperatures $\left(>100^{\circ} \mathrm{C}\right)$ and high protein concentrations, pose a challenge. A closed cavity rheometer has been proposed for this task [34-36] as it overcomes many of the limitations of conventional methods for this purpose. This device has already been applied to measure the rheological properties of diverse plant-based protein-rich raw materials $[3,34,36-45]$. These studies were limited to conventional protein sources, such as soybean, wheat, and pea. Furthermore, the measurement conditions (such as temperature, water content, etc.) are very different, so that a comparison between the different study results is only possible to a limited extent. Thus, it is not known how strongly the rheological properties of different raw materials can vary and therefore it is not possible to estimate how strongly the process and product are influenced by the raw material selection or composition.

The objective of this work is therefore to determine and compare the rheological properties of various plant-based protein-rich raw materials. In order to cover as broad a spectrum as possible, 11 different, commercially available raw materials were selected for this work. Five of them are from soy, and the other six from pea, oat, rice, potato, wheat, and canola. The selection of soy raw materials should cover different manufacturing processes, and the six other raw materials should cover different plant origins. The rheological properties of the raw materials are determined with a closed cavity rheometer at a moisture content of $30 \%(w / w)$ and a temperature of $120^{\circ} \mathrm{C}$, which corresponds to typical extrusion conditions. First, the development of viscosity over time will be observed. Subsequently, the strain-dependent rheological behaviour will be determined and compared by means of strain sweeps and the (visco-)elastic properties by means of stress relaxation tests.

\section{Material and Methods}

\subsection{Material}

The investigated plant-based raw materials are listed in Table 1. Protein contents are given by the manufacturers. Moisture content was determined gravimetrically by weighing a defined amount of material before and after drying at $105^{\circ} \mathrm{C}$ until mass-consistency. Short names given in the first column will be used hereafter.

\subsection{Dough Preparation}

Doughs for the rheological measurements were prepared by mixing the material with deionized water (Millipore Sigma, Burlington, USA) in a Thermomix (Vorwerk, Wuppertal, Germany) to achieve a moisture content of $30 \%(w / w)$, taking into account moisture content of raw material. Doughs were vacuum-sealed and stored in a refrigerator at $8{ }^{\circ} \mathrm{C}$ for at least $16 \mathrm{~h}$ to ensure equilibrium of hydration. All doughs were prepared in duplicate and all measurements were performed at least three times per mixture.

\subsection{Rheological Measurements}

Rheological measurements were performed using a closed cavity rheometer (CCR) from TA Instruments, Inc. (New Castle, DE, USA), as shown in Figure 1. Since details on the device are described elsewhere [34,35,45], only a brief description is given here. The dough (approximately $5.5 \mathrm{~g}$ per measurement) is placed between the two cones and the 
cavity is closed by moving the cones together. The cavity is pressurized up to $4500 \mathrm{kPa}$, which prevents moisture loss and allows measurement at high temperatures. The resulting force from the sinusoidal rotational deformation of the lower cone is monitored and used for calculation of the rheological properties.

Table 1. List of investigated plant-based raw materials.

\begin{tabular}{|c|c|c|c|c|c|}
\hline Short Name & Plant Origin & Brand Name & Manufacturer & $\begin{array}{l}\text { Protein Content } \\
\text { (Dry Basis) }\end{array}$ & Moisture Content \\
\hline SPI 1 & Soy & Supro ST & Solae & $>90 \%$ & $3.4 \%$ \\
\hline SPI 2 & Soy & PRO-FAM 974 & $\mathrm{ADM}$ & $>90 \%$ & $2.7 \%$ \\
\hline SPI 3 & Soy & SUPRO 500E IP & Solae & $>90 \%$ & $4.8 \%$ \\
\hline SPI 4 & Soy & PRO-FAM 781 & ADM & $>90 \%$ & $5.6 \%$ \\
\hline SPC & Soy & Alpha 8 IP & Solae & $>67 \%$ & $5.1 \%$ \\
\hline PeaPI & Pea & Nutralys S85 Plus N & Roquette & $>84 \%$ & $2.5 \%$ \\
\hline OPF & Oat & PrOatein & Tate\&Lyle & $>50 \%$ & $3.0 \%$ \\
\hline RPC & Rice & Remypro N80+ & Beneo & $>79 \%$ & $4.6 \%$ \\
\hline PoPC & Potato & Protastar & Avebe & $>76.5 \%$ & $6.4 \%$ \\
\hline WG & Wheat & Vital Wheat Gluten & Kröner-Stärke & $>83 \%$ & $4.5 \%$ \\
\hline CPI & Canola & Canola Pro & DSM & $>90 \%$ & $4.6 \%$ \\
\hline
\end{tabular}

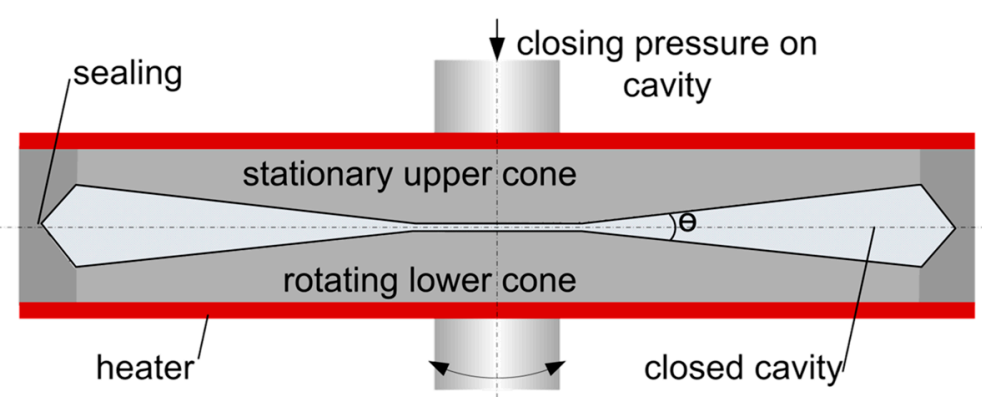

Figure 1. Closed cavity rheometer used for rheological measurements (picture taken from Emin \& Schuchmann, 2017 [35]).

\subsubsection{Time Sweeps}

In isothermal time sweep analyses, the material is treated at a defined temperature and the corresponding rheological properties are measured as a function of time. This methodology has already been used, for example, to track polymerization and degradation reactions in highly-concentrated wheat gluten [45]. In the present study, time sweep measurements were performed at $120^{\circ} \mathrm{C}$ for $120 \mathrm{~s}$, with an oscillatory shear deformation defined by a strain of $0.98 \%$ and a frequency of $1.0 \mathrm{~Hz}$, which equals a shear rate of $0.06 \mathrm{~s}^{-1}$. According to the strain sweeps, frequency and strain of the time sweeps were in the linear viscoelastic range (LVE) for all materials, so that no effect of the measurements shear deformation on the material is ensured.

\subsubsection{Strain Sweeps}

In the strain sweep measurements, the sample is treated at a defined temperature and frequency of oscillatory shear deformation, and the strain of deformation is stepwisely increased. This allows analysis of material behaviour in the linear viscoelastic range (at small strains), but also in the non-linear viscoelastic range (at high strains), which is expected to be especially relevant for process behaviour in extrusion [41]. In the present study, the strain sweep measurements were performed at $120^{\circ} \mathrm{C}$, with a frequency of 
$1.0 \mathrm{~Hz}$, after a pre-treatment of the material for $60 \mathrm{~s}$ at $120{ }^{\circ} \mathrm{C}, 0.98 \%$ and $1.0 \mathrm{~Hz}$. The short pre-treatment ensures that sample temperature is constant when the strain sweep starts.

\subsubsection{Stress Relaxation Tests}

Stress relaxation tests were used to investigate elastic properties of the materials. For this purpose, the material experiences a sudden step-strain, and this step-strain is maintained by the device; the required stress is then determined as a function of time. In the present study, stress relaxation tests were performed in two steps at $120^{\circ} \mathrm{C}$. In the first step, material was pre-treated for $60 \mathrm{~s}$ at $0.98 \%$ and a frequency of $1.0 \mathrm{~Hz}$ to ensure constant temperature of the sample. In the second step, a pre-step strain of $0.1 \%$ was applied for $15 \mathrm{~s}$, before the actual sudden step strain of $80 \%$ was maintained for $105 \mathrm{~s}$ and the required stress measured.

\section{Results and Discussion}

\subsection{Development of Material Viscosity over Time}

In an extrusion process, protein-rich raw materials are subjected to high thermal and mechanical stresses [46]. These can cause reactions of the present proteins, which affect the rheological properties $[36,44]$. Thus, the rheological properties are not only a function of temperature and shear rate, but also of the processing time. Therefore, time sweeps were performed at extrusion-like conditions (i.e., high temperature and high raw material concentration), and the development of viscosity over time was observed. Clear differences were found in these time sweeps between the raw materials (Figure 2).

Except for WG and CPI, most of the raw materials have a very similar curve shape. The viscosity decreases at the beginning, as measurement starts immediately after closing of the cavity, but the sample first heats up to the measuring temperature (i.e., from room temperature to $120^{\circ} \mathrm{C}$ ). Subsequently, the viscosity curve flattens out considerably and changes to a comparatively small increase in viscosity over time. The highest increase over time is observed here with SPI $4(41 \mathrm{kPa} \cdot \mathrm{s}$ to $50 \mathrm{kPa} \cdot \mathrm{s})$, while the other raw materials show lower viscosity increases.

In contrast, the curve shapes of WG and CPI are distinguished by a significant increase in viscosity. The viscosity of WG increases 5 -fold from $4 \mathrm{kPa} \cdot \mathrm{s}$ to $20 \mathrm{kPa} \cdot \mathrm{s}$ in two minutes, while a more than 20-fold increase in less than a minute from $2 \mathrm{kPa} \cdot \mathrm{s}$ to $42 \mathrm{kPa} \cdot \mathrm{s}$ can be observed for CPI. Presumably, the treatment conditions cause reactions of the proteins which are accompanied by an increase in molecular weight and thus viscosity [47]. Wheat proteins, for example, are known to polymerize under similar conditions $[44,45,48]$. These protein reactions do not seem to take place, or only to a very small extent, in those raw materials for which only a small viscosity increase is seen. On the one hand, this could be due to the fact that the temperature is not high enough to induce reactions. On the other hand, the thermomechanical and environmental stresses (e.g., enzymatic and $\mathrm{pH}$ treatment) in the manufacturing process of the raw materials could have influenced the (native) protein structure and thus led to a reduction or loss of reactivity [21,49-51].

These differences in viscosity development would also have consequences for the development of rheological properties in the extrusion process. For less reactive materials, such as the investigated SPI or PeaPI, only local conditions such as the material temperature would be decisive for the rheological behaviour in the extrusion process. However, the rheological behaviour of reactive materials, such as the investigated WG and CPI, is additionally a function of the processing history, e.g., the process residence time.

The investigated raw materials not only show differences in the development of viscosity over time but also in the magnitude of viscosity. As a representative value, the viscosity value after a treatment time of $60 \mathrm{~s}$ will be compared, which corresponds to a typical average residence time in a food extrusion process [52,53]. In the comparison of soy-based protein isolates, viscosity ranges from $14 \mathrm{kPa} \cdot \mathrm{s}$ (SPI 4) to $44 \mathrm{kPa} \cdot \mathrm{s}$ (SPI 1), with SPI $2(43 \mathrm{kPa} \cdot \mathrm{s})$ and SPI $3(34 \mathrm{kPa} \cdot \mathrm{s})$ in between. These differences can probably be attributed to different manufacturing processes, since plant origin and protein content are 
the same $[22,23]$. The thermomechanical and environmental stresses in the manufacturing process can in fact not only lead to a reduction in reactivity, as mentioned, but can also be used specifically to adjust the physicochemical and thus the rheological properties of the raw materials [22]. The SPC has at least twice the viscosity $(101 \mathrm{kPa} \cdot \mathrm{s})$ of the different SPIs. On the one hand, this could be due to differences in protein structure, as the manufacturing process has much less influence on the protein structure of SPC than in the case of SPI [49]. On the other hand, the protein content is lower ( $67 \%$ instead of $90 \%)$, and the proportion of polysaccharides is thus significantly higher [49,54-56]. The viscosity-increasing effect of polysaccharides has already been shown for a comparable system [34] and could also be the reason for the higher viscosity of SPC here.

When all raw materials are compared, the viscosity ranges from $11 \mathrm{kPa} \cdot \mathrm{s}$ for PeaPI to $165 \mathrm{kPa} \cdot \mathrm{s}$ of PoPC, which is a 15-fold difference. These differences could be due in part to the plant origin, which directly affects amino acid composition and molecular structure $[18,19]$. However, the polysaccharide component also seems to have a major influence here, as the raw materials with the highest viscosity, RPC ( $80 \mathrm{kPa} \cdot \mathrm{s})$ and PoPC, also have a comparatively high polysaccharide content. OPF (22 $\mathrm{kPa} \cdot \mathrm{s})$ has a high polysaccharide content, but at the same time a high lipid content (17\%) [11], which could be the reason for the low viscosity: the viscosity-reducing effect of lipids in comparable systems is well known [40,57].

Such large differences in viscosity as those determined (up to 15-fold) would be expected to have a significant effect on the extrusion process. For example, an increase in viscosity would lead to a proportional increase in shear stresses, significantly affecting physical and chemical changes, especially in the screw section [26]. Since the process pressures are also a direct function of the viscosity, the expansion behaviour and thus the product properties would also be largely influenced.

\subsection{Comparison of Strain-Dependent Rheological Behaviour}

The time sweeps in this study are carried out at a constant low frequency and strain of deformation to ensure that the mechanical stress generated by the measurement had no (irreversible) influence on the material. However, since a wide distribution of shear rates from 0 up to $5000 \mathrm{~s}^{-1}[58,59]$ can prevail in extrusion processes, the rheological behaviour at high strains is also deemed important [41]. To reflect this, strain sweeps were used to determine and compare the strain-dependent rheological behaviour of the raw materials (Figure 3).

General information on material behaviour can be obtained from the curve shapes of $G^{\prime}$ and $G^{\prime \prime}$ as a function of the strain. In the linear viscoelastic range (LVE), i.e., for small strains, the storage modulus $G^{\prime}$ is larger than the loss modulus $G^{\prime \prime}$, which indicates gel behaviour [60]. Additionally, plateau-like behaviour of $\mathrm{G}^{\prime}$ is apparent in the LVE, i.e., no or little dependence on strain. With increasing strain, the plateau of $G^{\prime}$ changes to the nonlinear viscoelastic range (nLVE): here, $\mathrm{G}^{\prime}$ decreases significantly with increasing strain, a so-called strain thinning behaviour. Both, gel behaviour and strain thinning behaviour, are typical for highly-concentrated protein-rich raw materials [34,41].

In a comparison of the G" curves, the so-called "weak strain overshoot" effect is apparent for almost all raw materials: with increasing strain, $G^{\prime \prime}$ first increases, reaches a maximum, and then drops again [61]. The exact trajectories of this effect (e.g., the shape and height of the maximum) differ between raw materials, suggesting differences in material behaviour [62]. However, a clear interpretation of this phenomenon remains challenging [63] and should not be discussed in depth in this study.

In order to allow quantitative comparison of the strain sweeps, the respective maximum strain value above which the curve drops (referred to as "range of LVE" in the following) will serve as a basis for the discussion. High values of the range of LVE indicate a more elastic network, i.e., the material is stronger and more resistant to strain (forces) [39,62]. For example, WG, which has the highest range of LVE $(44.2 \%)$, is known to form a very elastic and stretchable protein network $[64,65]$. 
For the soy-based protein isolates, the range of LVE spans from $2.6 \%$ for SPI 4 to $20.1 \%$ for SPI 1-3, assuming that these differences are due to different manufacturing processes. The range of LVE for the SPC (5.2\%) is significantly lower than for SPI 1-3, although it has twice the viscosity (Figure 2). The influence of the polysaccharide component is expected to lead to a comparatively lower range of LVE. In a previous work [34] it was shown that the addition of a polysaccharide leads to a lower range of LVE, and it was suggested that the formation of a dispersed polysaccharide phase could be the reason why the behaviour at high strains is influenced. In a comparison of all raw materials, the range of LVE spans from $1.9 \%$ for PeaPI and OPF to $44.2 \%$ for WG. Despite their high viscosity, RPC (7.4\%) and PoPC (10.3\%) show only a relatively low range of LVE, presumably also caused by the polysaccharide component.

These large differences in the range of LVE could, for example, have a distinct influence in extrusion processes for the production of meat analogues, as suggested in recent studies [39]. High range of LVE can be linked to an elastic/stable product texture and low range of LVE to a brittle/muddy product texture. This relationship may explain, for example, why the four raw materials with the highest range of LVE in this study (SPI 1, SPI 2, SPI 3, and WG) have already been applied in the high moisture extrusion of meat analogues $[3,4,66,67]$, where a stable/cohesive or elastic texture of the product is desired [68].

\subsection{Comparison of Elastic Behaviour}

Analogue to viscosity, elasticity also plays a major role in extrusion processes, e.g., expansion at the die outlet is significantly influenced by it [27-30]. Stress relaxation tests can be performed to investigate the (visco-)elastic behaviour of materials [69]. These tests can be a valuable enhancement in rheological characterization: they allowed, for example, to distinguish between highly concentrated materials of different origin, which was not possible with conventional oscillatory measurements [70]. Comparison of the stress relaxation test results (Figure 4) reveals clear differences in the (visco-)elastic behaviour of the raw materials.

The basic curve shape is the same for all raw materials: they exhibit a constant, relatively low value of stress up to $15 \mathrm{~s}$, which is due to the constant pre-step strain of $0.1 \%$. At $15 \mathrm{~s}$, the sudden step strain leads to an immediate stress increase up to the maximum value of the curves. Thereafter, the value decreases monotonically, which is a typical behaviour for viscoelastic materials [69]. Purely elastic materials, for example, would not show a decrease in stress over time, but a constant stress.

Quantitative comparison of the stress relaxation tests will be done with the respective maximum value of the shear stress, which can be correlated with the elastic behaviour of the material [71]. For the soy-based protein isolates, this value ranges from $9 \mathrm{kPa}$ for SPI 4 to $249 \mathrm{kPa}$ for SPI 2, which is more than a 27-fold difference. The values of SPI 1 (202 kPa) and SPI $3(204 \mathrm{kPa})$ rank between SPI 4 and SPI 2. These differences, which again are presumably due to the manufacturing process, are thus relatively larger than the differences in viscosities between the soy protein isolates, where there is only about a 3-fold difference $(14 \mathrm{kPa} \cdot \mathrm{s}$ to $44 \mathrm{kPa} \cdot \mathrm{s})$. The SPC (253 kPa) has only a slightly higher maximum shear stress than the SPI 2.

In a comparison of all raw materials, the value for the maximum shear stress ranges from $9 \mathrm{kPa}$ for SPI 4 to $482 \mathrm{kPa}$ for PoPC, which corresponds to a 53-fold difference and is thus also greater in relative terms than for the viscosities compared. Here, the raw materials with a comparatively low viscosity tend to have a comparatively low maximum shear stress (ergo elasticity), and raw materials with a high viscosity also tend to have a higher maximum shear stress. However, the actual order of the raw materials in the comparisons does not match. For example, CPI has a lower viscosity than RPC (39 kPa.s to $80 \mathrm{kPa} \cdot \mathrm{s})$, but a higher maximum shear stress $(170 \mathrm{kPa}$ to $144 \mathrm{kPa})$. 


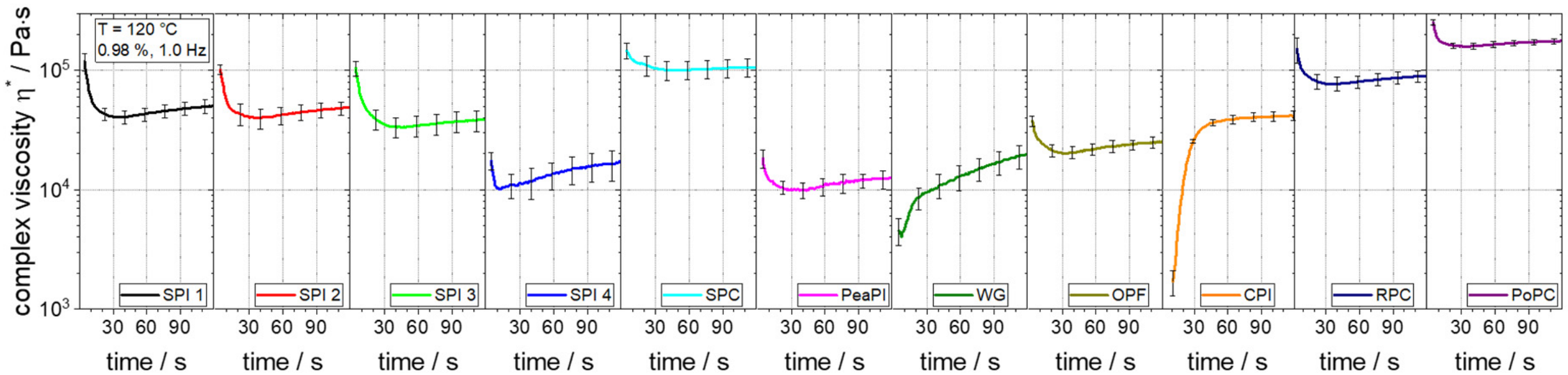

Figure 2. Time sweeps at $120^{\circ} \mathrm{C}$ and $0.98 \% / 1.0 \mathrm{~Hz}$ of different raw materials at a moisture content of $30 \%$.

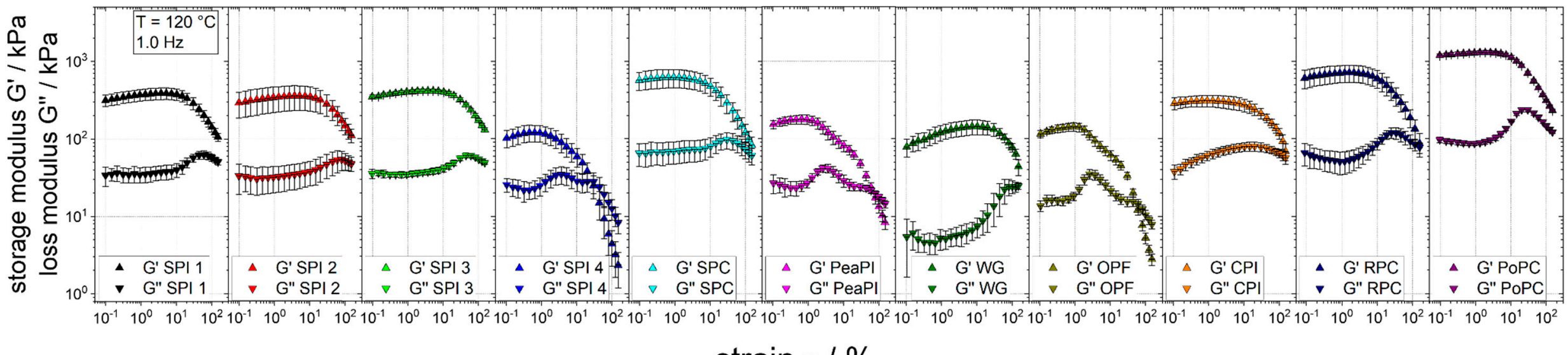

\section{strain $\gamma / \%$}

Figure 3. Strain sweeps at $120{ }^{\circ} \mathrm{C}$ and $1.0 \mathrm{~Hz}$ of different raw materials at a moisture content of $30 \%$. 


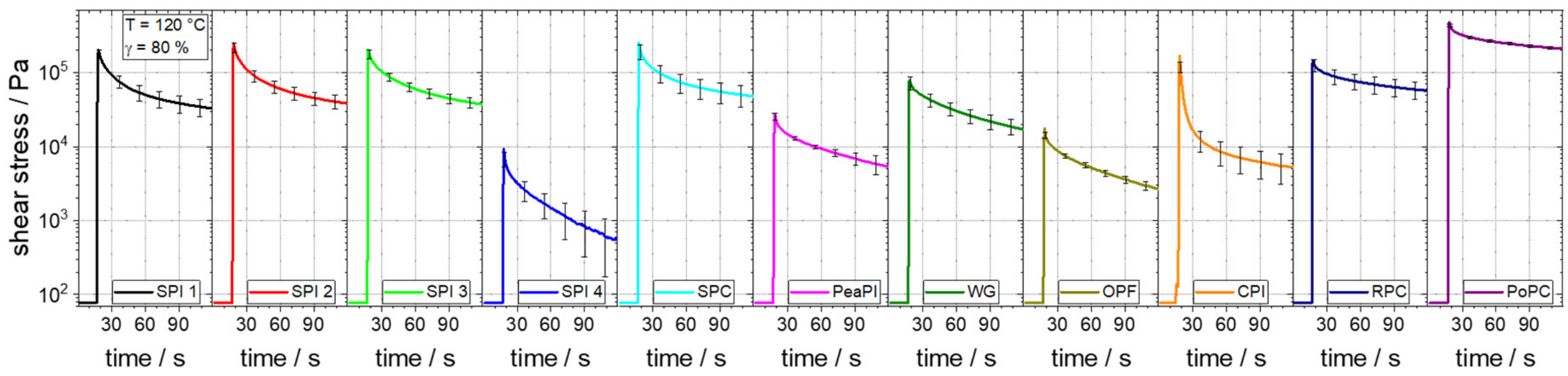

Figure 4. Stress relaxation tests at $120{ }^{\circ} \mathrm{C}$ and a strain of $80 \%$ of different raw materials at a moisture content of $30 \%$. 
The differences in elasticity between the raw materials are also expected to have an impact on the extrusion process. For instance, a comparably much smaller decrease of elastic properties as the measured ones has already lead to a significant decrease of the sectional expansion in a starch-based matrix [28].

\section{Conclusions}

The objective of this work was to determine and compare the rheological properties of eleven plant-based protein-rich raw materials. The raw materials were rheologically characterized by means of time sweeps, strain sweeps, and stress relaxation tests. In the time sweeps, two raw materials (WG and CPI) showed a significant increase (up to 20-fold) in viscosity over time, while the nine other raw materials showed only a comparatively small increase in viscosity. Furthermore, the raw materials differed significantly in the magnitude of viscosity after one minute. Among the four soy-based protein isolates, viscosity ranged from $14 \mathrm{kPa} \cdot \mathrm{s}$ to $44 \mathrm{kPa} \cdot \mathrm{s}$, corresponding to a 3 -fold difference. Meanwhile, comparison of all raw materials revealed a 15 -fold difference in viscosity (range from $11 \mathrm{kPa} \cdot \mathrm{s}$ to $165 \mathrm{kPa} \cdot \mathrm{s}$ ). The strain sweeps showed that all the raw materials exhibited gel behaviour and strain thinning behaviour, while the quantitative dimensions of the weak strain overshoot effect varied. The values for the range of LVE for the four soy-based protein isolates range from $2.6 \%$ to $20.1 \%$; when all raw materials are compared, this value shows a range from $1.9 \%$ to $44.2 \%$. The stress relaxation tests could show that all raw materials exhibit the typical relaxation behaviour of viscoelastic materials. The maximum shear stress, which can be correlated with the elastic properties, ranges for the soy-based protein isolates from $9 \mathrm{kPa}$ to $249 \mathrm{kPa}$, which corresponds to a more than 27-fold difference. The difference is even greater when all raw materials are compared: a 53-fold differences is apparent here ( $9 \mathrm{kPa}$ to $482 \mathrm{kPa}$ ). The measurements allowed to identify distinct differences between the rheological properties of the raw materials, even when plant origin and protein content were identical. The combination of all three methods for any given raw material offers an extensive and valuable insight into rheological behaviour. Since rheological properties can have a distinct impact on the extrusion process, the presented rheological approach and the obtained results can be used to adapt the raw material selection and/or composition to process and product design requirements and help to meet the challenge of applying plant-based proteins in food extrusion.

Author Contributions: Conceptualization, P.W. and M.A.E.; methodology, P.W.; validation, P.W.; investigation, P.W.; writing — original draft preparation, P.W.; writing—review and editing, G.W., H.P.K. and M.A.E. All authors have read and agreed to the published version of the manuscript.

Funding: The APC was funded by the KIT-Publication Fund of the Karlsruhe Institute of Technology.

Institutional Review Board Statement: Not applicable.

Informed Consent Statement: Not applicable.

Data Availability Statement: Not applicable.

Acknowledgments: The authors would like to express their gratitude to Nina Weis and Tobias Behrendt for supporting the rheological measurements.

Conflicts of Interest: The authors declare no conflict of interest. The company had no role in the design of the study; in the collection, analyses, or interpretation of data; in the writing of the manuscript; or in the decision to publish the results.

\section{References}

1. Melina, V.; Craig, W.J.; Levin, S. Position of the academy of nutrition and dietetics: Vegetarian diets. J. Acad. Nutr. Diet. 2016, 116, 1970-1980. [CrossRef]

2. Dwyer, J.T. Nutritional consequences of vegetarianism. Annu. Rev. Nutr. 1991, 11, 61-91. [CrossRef]

3. Wittek, P.; Zeiler, N.; Karbstein, H.P.; Emin, M.A. High moisture extrusion of soy protein: Investigations on the formation of anisotropic product structure. Foods 2021, 10, 102. [CrossRef] 
4. Pietsch, V.L.; Emin, M.A.; Schuchmann, H.P. Process conditions influencing wheat gluten polymerization during high moisture extrusion of meat analog products. J. Food Eng. 2017, 198, 28-35. [CrossRef]

5. Osen, R.; Toelstede, S.; Wild, F.; Eisner, P.; Schweiggert-Weisz, U. High moisture extrusion cooking of pea protein isolates: Raw material characteristics, extruder responses, and texture properties. J. Food Eng. 2014, 127, 67-74. [CrossRef]

6. Chen, F.L.; Wei, Y.M.; Zhang, B.; Ojokoh, A.O. System parameters and product properties response of soybean protein extruded at wide moisture range. J. Food Eng. 2010, 96, 208-213. [CrossRef]

7. Martin, A.; Osen, R.; Karbstein, H.P.; Emin, M.A. Impact of rapeseed press cake on the rheological properties and expansion dynamics of extruded maize starch. Foods 2021, 10, 616. [CrossRef] [PubMed]

8. Philipp, C.; Emin, M.A.; Buckow, R.; Silcock, P.; Oey, I. Pea protein-fortified extruded snacks: Linking melt viscosity and glass transition temperature with expansion behaviour. J. Food Eng. 2018, 217, 93-100. [CrossRef]

9. Philipp, C.; Buckow, R.; Silcock, P.; Oey, I. Instrumental and sensory properties of pea protein-fortified extruded rice snacks. Food Res. Int. 2017, 102, 658-665. [CrossRef]

10. Jones, O.G. Recent advances in the functionality of non-animal-sourced proteins contributing to their use in meat analogs. Curr. Opin. Food Sci. 2016, 7, 7-13. [CrossRef]

11. De Angelis, D.; Kaleda, A.; Pasqualone, A.; Vaikma, H.; Tamm, M.; Tammik, M.-L.; Squeo, G.; Summo, C. Physicochemical and sensorial evaluation of meat analogues produced from dry-fractionated pea and oat proteins. Foods 2020, 9, 1754. [CrossRef] [PubMed]

12. Zhang, B.; Liu, G.; Ying, D.; Sanguansri, L.; Augustin, M.A. Effect of extrusion conditions on the physico-chemical properties and in vitro protein digestibility of canola meal. Food Res. Int. 2017, 100, 658-664. [CrossRef] [PubMed]

13. Palanisamy, M.; Franke, K.; Berger, R.G.; Heinz, V.; Töpfl, S. High moisture extrusion of lupin protein: Influence of extrusion parameters on extruder responses and product properties. J. Sci. Food Agric. 2019, 99, 2175-2185. [CrossRef] [PubMed]

14. Zhang, J.; Liu, L.; Jiang, Y.; Faisal, S.; Wang, Q. A new insight into the high-moisture extrusion process of peanut protein: From the aspect of the orders and amount of energy input. J. Food Eng. 2020, 264, 109668. [CrossRef]

15. Rehrah, D.; Ahmedna, M.; Goktepe, I.; Yu, J. Extrusion parameters and consumer acceptability of a peanut-based meat analogue. Int. J. Food Sci. Nutr. 2009, 44, 2075-2084. [CrossRef]

16. Aguilera, J.M.; Rossi, F.; Hiche, E.; Chichester, C.O. Development and evaluation of an extrusion-texturized peanut protein. J. Food Sci. 1980, 45, 246-250. [CrossRef]

17. Zahari, I.; Ferawati, F.; Helstad, A.; Ahlström, C.; Östbring, K.; Rayner, M.; Purhagen, J.K. Development of high-moisture meat analogues with hemp and soy protein using extrusion cooking. Foods 2020, 9, 772. [CrossRef] [PubMed]

18. Gorissen, S.H.M.; Crombag, J.J.R.; Senden, J.M.G.; Waterval, W.A.H.; Bierau, J.; Verdijk, L.B.; van Loon, L.J.C. Protein content and amino acid composition of commercially available plant-based protein isolates. Amino Acids 2018, 50, 1685-1695. [CrossRef] [PubMed]

19. Day, L. Proteins from land plants_-Potential resources for human nutrition and food security. Trends Food Sci. Tech. 2013, 32, 25-42. [CrossRef]

20. Arrese, E.L.; Sorgentini, D.A.; Wagner, J.R.; Anon, M.C. Electrophoretic, solubility and functional properties of commercial soy protein isolates. J. Agric. Food Chem. 1991, 39, 1029-1032. [CrossRef]

21. Moure, A.; Sineiro, J.; Domínguez, H.; Parajó, J.C. Functionality of oilseed protein products: A review. Food Res. Int. 2006, 39, 945-963. [CrossRef]

22. Añón, M.C.; Sorgentini, D.A.; Wagner, J.R. Relationships between different hydration properties of commercial and laboratory soybean isolates. J. Agric. Food Chem. 2001, 49, 4852-4858. [CrossRef]

23. Wagner, J.R.; Sorgentini, D.A.; Añón, M.C. Relation between solubility and surface hydrophobicity as an indicator of modifications during preparation processes of commercial and laboratory-prepared soy protein isolates. J. Agric. Food Chem. 2000, 48, 3159-3165. [CrossRef] [PubMed]

24. Sheard, P.R.; Mitchell, J.R.; Ledward, D.A. Extrusion behaviour of different soya isolates and the effect of particle size. Int. J. Food Sci. Nutr. 1986, 21, 627-641. [CrossRef]

25. Emin, M.A.; Schuchmann, H.P. Droplet breakup and coalescence in a twin-screw extrusion processing of starch based matrix. J. Food Eng. 2013, 116, 118-129. [CrossRef]

26. Einde, R.V.D.; Akkermans, C.; van der Goot, A.J.; Boom, R. Molecular breakdown of corn starch by thermal and mechanical effects. Carbohydr. Polym. 2004, 56, 415-422. [CrossRef]

27. Horvat, M.; Emin, M.A.; Hochstein, B.; Willenbacher, N.; Schuchmann, H.P. A multiple-step slit die rheometer for rheological characterization of extruded starch melts. J. Food Eng. 2013, 116, 398-403. [CrossRef]

28. Robin, F.; Dattinger, S.; Boire, A.; Forny, L.; Horvat, M.; Schuchmann, H.P.; Palzer, S. Elastic properties of extruded starchy melts containing wheat bran using on-line rheology and dynamic mechanical thermal analysis. J. Food Eng. 2012, 109, 414-423. [CrossRef]

29. Valle, G.; Vergnes, B.; Colonna, P.; Patria, A. Relations between rheological properties of molten starches and their expansion behaviour in extrusion. J. Food Eng. 1997, 31, 277-295. [CrossRef]

30. Lai, L.S.; Kokini, J.L. Physicochemical changes and rheological properties of starch during extrusion. (A review). Biotechnol. Prog. 1991, 7, 251-266. [CrossRef] 
31. Tolstoguzov, V.B. Thermoplastic extrusion-the mechanism of the formation of extrudate structure and properties. J. Am. Oil Chem. Soc. 1993, 70, 417-424. [CrossRef]

32. Cheftel, J.C.; Kitagawa, M.; Quéguiner, C. New protein texturization processes by extrusion cooking at high moisture levels. Food Rev. Int. 1992, 8, 235-275. [CrossRef]

33. Wittek, P.; Ellwanger, F.; Karbstein, H.P.; Emin, M.A. Morphology development and flow characteristics during high moisture extrusion of a plant-based meat analogue. Foods 2021. submitted.

34. Wittek, P.; Zeiler, N.; Karbstein, H.P.; Emin, M.A. Analysis of the complex rheological properties of highly concentrated proteins with a closed cavity rheometer. Appl. Rheol. 2020, 30, 64-76. [CrossRef]

35. Emin, M.A.; Schuchmann, H.P. A mechanistic approach to analyze extrusion processing of biopolymers by numerical, rheological, and optical methods. Trends Food Sci. Tech. 2017, 60, 88-95. [CrossRef]

36. Pommet, M.; Morel, M.-H.; Redl, A.; Guilbert, S. Aggregation and degradation of plasticized wheat gluten during thermomechanical treatments, as monitored by rheological and biochemical changes. Polymer 2004, 45, 6853-6860. [CrossRef]

37. Pietsch, V.L.; Bühler, J.M.; Karbstein, H.P.; Emin, M.A. High moisture extrusion of soy protein concentrate: Influence of thermomechanical treatment on protein-protein interactions and rheological properties. J. Food Eng. 2019, 251, 11-18. [CrossRef]

38. Wittek, P.; Karbstein, H.P.; Emin, M.A. Blending proteins in high moisture extrusion to design meat analogues: Rheological properties, morphology development and product properties. Foods 2021, 10, 1509. [CrossRef]

39. Schreuders, F.K.G.; Sagis, L.M.; Bodnár, I.; Erni, P.; Boom, R.M.; van der Goot, A.J. Mapping the texture of plant protein blends for meat analogues. Food Hydrocoll. 2021, 106753. [CrossRef]

40. Kendler, C.; Duchardt, A.; Karbstein, H.P.; Emin, M.A. Effect of oil content and oil addition point on the extrusion processing of wheat gluten-based meat analogues. Foods 2021, 10, 697. [CrossRef]

41. Schreuders, F.K.G.; Sagis, L.; Bodnár, I.; Erni, P.; Boom, R.M.; van der Goot, A.J. Small and large oscillatory shear properties of concentrated proteins. Food Hydrocoll. 2021, 110, 106172. [CrossRef]

42. Dekkers, B.L.; Boom, R.M.; van der Goot, A.J. Viscoelastic properties of soy protein isolate-pectin blends: Richer than those of a simple composite material. Food Res. Int. 2018, 107, 281-288. [CrossRef] [PubMed]

43. Dekkers, B.L.; Emin, M.A.; Boom, R.M.; van der Goot, A.J. The phase properties of soy protein and wheat gluten in a blend for fibrous structure formation. Food Hydrocoll. 2018, 79, 273-281. [CrossRef]

44. Pietsch, V.L.; Karbstein, H.P.; Emin, M.A. Kinetics of wheat gluten polymerization at extrusion-like conditions relevant for the production of meat analog products. Food Hydrocoll. 2018, 85, 102-109. [CrossRef]

45. Emin, M.A.; Quevedo, M.; Wilhelm, M.; Karbstein, H.P. Analysis of the reaction behavior of highly concentrated plant proteins in extrusion-like conditions. Innov. Food Sci. Emerg. Technol. 2017, 44, 15-20. [CrossRef]

46. Bouvier, J.-M.; Campanella, O. Extrusion Processing Technology: Food and Non-Food Biomaterials; John Wiley \& Sons Inc: Chichester, West Sussex, UK, 2014; ISBN 978-1-4443-3811-9.

47. Berry, G.C.; Fox, T. The viscosity of polymers and their concentrated solutions. In Fortschritte der Hochpolymeren-Forschung; Springer: Berlin/Heidelberg, Germany, 1968; pp. 261-357. ISBN 3-540-04032-3.

48. Pietsch, V.L.; Werner, R.; Karbstein, H.P.; Emin, M.A. High moisture extrusion of wheat gluten: Relationship between process parameters, protein polymerization, and final product characteristics. J. Food Eng. 2019, 259, 3-11. [CrossRef]

49. Preece, K.E.; Hooshyar, N.; Zuidam, N.J. Whole soybean protein extraction processes: A review. Innov. Food Sci. Emerg. Techn. 2017, 43, 163-172. [CrossRef]

50. Cogan, U.; Yaron, A.; Berk, Z.; Mizrahi, S. Isolation of soybean protein: Effect of processing conditions on yields and purity. J. Am. Oil Chem. Soc. 1967, 44, 321-324. [CrossRef]

51. Belter, P.A.; Smith, A.K. Protein denaturation in soybean meal during processing. J. Am. Oil Chem. Soc. 1952, 29, 170-174 [CrossRef]

52. Pietsch, V.L.; Schöffel, F.; Rädle, M.; Karbstein, H.P.; Emin, M.A. High moisture extrusion of wheat gluten: Modeling of the polymerization behavior in the screw section of the extrusion process. J. Food Eng. 2019, 246, 67-74. [CrossRef]

53. Koch, L.; Emin, M.A.; Schuchmann, H.P. Influence of processing conditions on the formation of whey protein-citrus pectin conjugates in extrusion. J. Food Eng. 2017, 193, 1-9. [CrossRef]

54. Kasai, N.; Imashiro, Y.; Morita, N. Extraction of soybean oil from single cells. J. Agric. Food Chem. 2003, 51, 6217-6222. [CrossRef]

55. Ouhida, I.; Pérez, J.F.; Gasa, J. Soybean (Glycine max) cell wall composition and availability to feed enzymes. J. Agric. Food Chem. 2002, 50, 1933-1938. [CrossRef]

56. Wolf, W.J. Soybean proteins. Their functional, chemical, and physical properties. J. Agric. Food Chem. 1970, 18, 969-976. [CrossRef]

57. Fu, J.; Mulvaney, S.J.; Cohen, C. Effect of added fat on the rheological properties of wheat flour doughs. Cereal Chem. 1997, 74, 304-311. [CrossRef]

58. Emin, M.A.; Wittek, P.; Schwegler, Y. Numerical analysis of thermal and mechanical stress profile during the extrusion processing of plasticized starch by non-isothermal flow simulation. J. Food Eng. 2021, 294, 110407. [CrossRef]

59. Emin, M.A.; Schuchmann, H.P. Analysis of the dispersive mixing efficiency in a twin-screw extrusion processing of starch based matrix. J. Food Eng. 2013, 115, 132-143. [CrossRef]

60. Mezger, T.G. The Rheology Handbook: For Users of Rotational and Oscillation Rheometers, 2nd ed.; Vincentz Network: Hannover, Germany, 2006; ISBN 3878701748. 
61. Hyun, K.; Kim, S.H.; Ahn, K.H.; Lee, S.J. Large amplitude oscillatory shear as a way to classify the complex fluids. J. Non-Newtonian Fluid Mech. 2002, 107, 51-65. [CrossRef]

62. Duvarci, O.C.; Yazar, G.; Kokini, J.L. The comparison of LAOS behavior of structured food materials (suspensions, emulsions and elastic networks). Trends Food Sci. Tech. 2017, 60, 2-11. [CrossRef]

63. Hyun, K.; Wilhelm, M.; Klein, C.O.; Cho, K.S.; Nam, J.G.; Ahn, K.H.; Lee, S.J.; Ewoldt, R.H.; McKinley, G.H. A review of nonlinear oscillatory shear tests: Analysis and application of large amplitude oscillatory shear (LAOS). Prog. Polym. Sci. 2011, 36, 1697-1753. [CrossRef]

64. Abang Zaid, D.N.; Chin, N.L.; Yusof, Y.A. A review on rheological properties and measurements of dough and gluten. J. Appl. Sci. 2010, 10, 2478-2490. [CrossRef]

65. Belton, P.S. Mini review: On the elasticity of wheat gluten. J. Cereal Sci. 1999, 29, 103-107. [CrossRef]

66. Lin, S.; Huff, H.E.; Hsieh, F. Texture and chemical characteristics of soy protein meat analog extruded at high moisture. J. Food Sci. 2000, 65, 264-269. [CrossRef]

67. Liu, K.; Hsieh, F.-H. Protein-protein interactions during high-moisture extrusion for fibrous meat analogues and comparison of protein solubility methods using different solvent systems. J. Agric. Food Chem. 2008, 56, 2681-2687. [CrossRef]

68. Wild, F.; Czerny, M.; Janssen, A.M.; Kole, A.; Zunabovic, M.; Domig, K.J. The evolution of a plant-based alternative to meat: From niche markets to widely accepted meat alternatives. Agro. Food Ind. Hi-Tech. 2014, 25, 45-49.

69. Steffe, J.F. Rheological Methods in Food Process Engineering, 2nd ed.; Freeman Press: East Lansing, MI, USA, 1996; ISBN 9780963203618.

70. Safari-Ardi, M.; Phan-Thien, N. Stress relaxation and oscillatory tests to distinguish between doughs prepared from wheat flours of different varietal origin. Cereal Chem. 1998, 75, 80-84. [CrossRef]

71. Rao, V.K.; Mulvaney, S.J.; Dexter, J.E. Rheological characterisation of long- and short- mixing flours based on stress-Relaxation. J. Cereal Sci. 2000, 31, 159-171. [CrossRef] 